\title{
The Success Models of Financing the Artificial Reproductive Techniques and the Albanian Case
}

Jonada Zyberaj

Dr., "Ismail Qemali" University of Vlore Faculty of Humanities Department of Law

\begin{abstract}
The development of the artificial reproduction techniques (ART) is obviously one of the biggest achievements of medicine of the XX Century accompanied by many ethical, moral, social and economic disputes. Even if its applicability makes the dream true for many couples, the high costs of the (ART) makes it realizable only for a few of them, fearing so to create another limitation on the access of these techniques. While aiming at the realization of the reproductive health of their citizens, states are still confused on whether to include (ART) in the health care policies and fund it fully or partially or to leave the cost of its implementation to the individual. Success cases of different European countries will be analyzed in this paper where the (ART) are fully or partially funded by the health care scheme. The reproductive health service in Albania is provided by law as a funded service, but until now (ART) is offered only by private clinics and although its cost is lower than that of European countries, it still remains high compared to the personal income. Having in consideration the success cases of European countries, this paper will try to analyze if there is the possibility in the Albanian legislation of financing the artificial reproduction techniques by the national health insurance fund.
\end{abstract}

Keywords: artificial reproductive techniques, costs, health care policy, funded health services

\section{Introduction}

The scheme of funding the health care services is a social and economic mechanism as well as political too. The purpose of any refund scheme is to ease the economic expense of a person and make it more affordable for the individual. The funding scheme can be seen as a cost transfer from the individual to the society. Therefore the economic burden of ART (artificial reproductive techniques) on the national health 
care is much easier for developed countries and as such the funding scheme aims to be more generous too. ${ }^{1}$

But regardless of the opportunities of funding, to what extent should the generosity of financing the ART be extended?

The health insurance scheme is mainly created as a result of these two components; poverty and disease. ${ }^{2}$ At the beginning, the aim of the health insurance scheme was to create possibilities of treatment in cases when disease is combined with poverty. The generosity and solidarity are the main principles of the health care system. ${ }^{3}$ All the individuals contribute to improve their health status, and also that of other individuals who are in a financial inability. Therefore the generosity in funding from the health care scheme is primarily based on the identification of a disease affecting the health status of the individual, and on the possibility of treatment for everyone without financial prejudice. The financial help from the health care system is not applied in cases when a certain health element doesn't affect the deterioration of the individual's health status.

The health coverage plans have expanded in accordance to the individuals need for health and financial insurance. The spread of new diseases, the evolution of medical technologies, and the expansion of medical benefits has redefined the concept of health coverage. ${ }^{4}$ The International Covenant on Economic, Social and Cultural Rights (ICECR), in Art 12 promotes and recognizes "... the right of everyone to the enjoyment of the highest attainable standard of physical and mental health" ${ }^{5}$, known as the right to health, which was firstly articulated in 1946 in the preamble of the Constitution of the World Health Organization, and in 1948 was mentioned in the Universal Declaration of Human Rights. ${ }^{6}$ The right to health is considered as a fundamental human right, indispensable for the exercise of other human rights, and it is a duty of the State to take the necessary measures for its full realization. ${ }^{7}$ The right to health refers to the right to the enjoyment of a variety of goods, facilities, and conditions which are necessary for having the highest attainable physical and mental health.

The United Nations International Conference on Population and Development (ICPD), defines reproductive health as "a state of complete physical, mental and social well being and not merely the absence of disease or infirmity, in all matters relating to the

\footnotetext{
${ }^{1}$ Ata B. Seli E. (2010) "Economics of assisted reproductive technologies", Current opinion in obstetrics \& gynecology , 22(3): 183-8.

2 Peto Zh, (2006), "Sistemet e mbrojtjes shoqërore", Shtypshkronja Ekpres, Tirane.

${ }^{3}$ N. A. S, N.A.E, I.M and N.R.C, (2001), "Crossing the Quality Chasm: A New Health System for the 21st Century", NA Press.

4 American Academy of Actuaries, "Fundamental of Insurance: Implications for Health Coverage", July 2008 https://www.actuary.org/pdf/health/coverage_ib_08.pdf retrieved 1/14/2018

${ }^{5}$ Art 12 of the International Covenant on Economic, Social and Cultural Rights, Adopted on 3 January 1976, United Nations of Human Rights.

${ }^{6}$ WHO, UN High Commissioner of Human Rights, "The Right to Health", Fact Sheet No.31, retrieved 1/14/2018 http://www.ohchr.org/Documents/Publications/Factsheet31.pdf

${ }^{7}$ Committee on Economic, Social and Cultural Rights, "CESCR General Comment No.14: The Right to the Highest Attainable Standard of Health (Art 12), http://www.refworld.org/pdfid/4538838d0.pdf
} 
reproductive system and to its function and processes" 1 Therefore reproductive health implies the "... the right and the capability to reproduce and the freedom to decide if, when and how often to do so". It implicit in the last condition "... the right to have access to different methods of their choice, for regulation of fertility which are not against the law, and the right of access to appropriate health care services that will enable women to go safely through pregnancy and childbirth..."2 This affirms that individuals have the right to choose the application of different forms of artificial reproduction to avoid infertility and also to pretend health care services, which can lead to a pregnancy and childbirth.

The artificial reproduction is one of the forms of exercising reproductive rights of the individuals, part of the right to reproductive health. In this sense, countries where the artificial reproduction techniques are allowed to avoid infertility should include within the health insurance scheme the ART as long as they relate and serve to the reproductive health. But the application of the ART is not only limited to infertility avoidance. Many European countries have allowed the access on ART for purposes beyond that of infertility. (United Kingdom, Belgium, France, Spain)

Since in the 1980, the definition of the legal criteria and that of the possibility of funding the reproductive techniques has been an important issue. According to some authors the purpose and the aim of using these techniques should be the main criteria. If these techniques would be considered and used to cure certain disease such as infertility, or they would be considered as techniques tended to meet a certain human need such as reproduction. ${ }^{3}$

The World Health Organization (WHO) has defined infertility as a "... disease of the reproductive system, a health restriction that connotes the individual to an inability to normal carry his natural functions". ${ }^{4}$ This leads to the conclusion that the artificial reproduction techniques, when they are intended for the reproduction of the infertile individuals, should be part of the health care scheme and the costs associated with these techniques, as well as the costs incurred to treat infertility, should be financed by the state.

Other authors assume that the impossibility to have children, regardless the infertility issue can be a cause of suffering for individuals, as suffering from the lack of children comes not only from the impossibility to have children, but at the same time because of the function of the social structure. In this sense, it may be justified to finance ART even for these groups of individuals. ${ }^{5}$

\footnotetext{
1 UN, International Conference on Population and Development, Program of Action, 5 - 13 September 1994, https://www.unfpa.org/sites/default/files/pub-pdf/programme_of_action_Web\%20ENGLISH.pdf

2 idem

${ }^{3}$ Martin J. (1996), "Prioritizing assisted conception services: A Public health perspective" Evans "Creating the child", Kluwer edt.

4 WHO, ICMART, "Revised glossary on ART terminology, 2009", Human Reproduction, Vol. 24, No. 11, 2009 http://www.who.int/reproductivehealth/publications/infertility/art_terminology.pdf

${ }^{5}$ Holm S., (1996), "The need for treatment", ed. Evans "Creating the child", Kluwer edt. 1996.
} 
The application of ART is a recent phenomenon in Albania and it is not well- defined. It is of a great importance to determine the importance of funding the ART as its important impact in increasing fertility rates.

\section{Methodology}

The methodology adopted for this paper is that of the bibliographic review on the subject matter that of the funding of the artificial reproductive techniques, as part of the reproductive health services in European countries and in Albania. The article seeks to examine the actual situation of the artificial reproductive health services in Albania and its possibility to include them as part of the health insurance scheme. In order to have a complete view on the reproductive health services, insurance schemes of different European countries are taken into consideration and compared between them. The content of the law on the reproductive health is examined and also the Albanian health insurance scheme is taken in examination in order to identify the problem leading to the lack of funding. Given that in Albania the legislative framework of reproductive health is not completed, a special attention is given to the National Health Strategy, in which the possibility of financing reproductive techniques is foreseen.

\section{Some European Experiences}

Developed European countries consider infertility as a medical condition or as a disease, rather than "a socially constructed need" as it is considered in the US. ${ }^{1}$ This leads to a greater use of IVF in countries that subsidize the expenses, than to countries in which the ART is not included in the insurance scheme. ${ }^{2}$ Even if they differ in the access policies of the ART, most of the European countries have deemed infertility as a health care good and their national policies fund all or some portion of infertility treatment. The coverage scheme depends on historical, social and economic considerations which combined with the medical and ethical ones define the coverage scheme. In compliance with the level of financing some of the European countries restrict access to the treatment by introducing eligible criteria such as age, marital status etc. Here are some successful cases on how European countries provide the possibility of funding the application of the artificial reproductive techniques.

Belgium funds ART in $100 \%$ of the first six cycles only for women under the age of 43. ${ }^{3}$ But the marital status is not a restriction according to the Belgium law. ${ }^{4}$

\footnotetext{
${ }^{1}$ Katz P., Nachtigall R., Showstack J., "The economic impact of the assisted reproductive technologies", Institute for Health Policy Studies, California USA, retrieved on 20.12.2017 https://www.nature.com/fertility/content/pdf/ncb-nm-fertilitys29.pdf

${ }^{2}$ Idem

In 1998 the use of IVF was three times greater in France, Netherlands, Norway and Sweden, than in US and five times greater in Denmark, Finland and Iceland.

${ }_{3}^{3}$ Service Public Federal Santé Publique, Securité de la Chaine Alimentaire et Environment 20032403, June 4, 2003, The Royal Decree of June 2003

${ }^{4}$ Belgium Law Concerning Medically-Assisted Insemination, 2007, art 4.
} 
French legislation provides only the access on ART of infertile, heterosexual couples. France provides full public funding of ART but limited only to heterosexual married couples, who are on a procreation age, under the age of 43 . Funding is limited to four cycles. ${ }^{1}$

Germany, like French provides the funding only for heterosexual married couples. There are age limitations too. In Germany only $50 \%$ of the cost is reimbursed. ${ }^{2}$

Great Britain the funding scheme covers fully or partially, when the service users have to pay only some of the medicines. The funding applies on heterosexual couples, single women and also to same sex couples and is covered by the National Health Plan. ${ }^{3}$

Nordic Countries seems to have a more liberal approach to artificial reproductive issues, including here that of financing the reproductive techniques. Denmark is known as the more liberal among them. In Denmark, from May 1997, the Danish Parliament decided that the artificial reproduction would be offered at the public hospitals free of charge. This was limited only to heterosexual couples. ${ }^{4}$ In 2004 an amendment of the '97 Bill agreed to limit the treatment of the heterosexual couples in public hospitals up to the birth of only one child. It was not until 2006 that artificial reproduction techniques were also made available to single women. From 2015, ART in Denmark is covered by the public health service for all involuntary childless women residing in Denmark, up to the age of 45 , regardless their sexual orientation or social status. $^{5}$

The criteria used to regulate the ART public coverage are more restrictive than the general criteria for the access to these techniques. Establishing restriction criteria is seen as a mean to limit the budget spending, which should be oriented towards the health system priorities. According to the ESHRE $^{6}$ survey 2013, the first most common restriction is that of the age, followed by that related to limitations of coverage only for the first child, or limits on the total number of cycles offered. ${ }^{7}$

The criteria, on which different countries have assessed or not the financing of ART, are based on the cost - effectiveness analyses and to the ratio of the conventional forms of treating infertility and ART. ${ }^{8}$ Cost analysis is based in the so called availability

\footnotetext{
${ }^{1}$ French Human Fertility and Embryology Bill, 2007-2008

${ }^{2}$ German Social Code V.

${ }^{3}$ Keane M., Long J., O'Nolan G., Farragher L., ( 2017), "Assisted reproductive technologies: International approaches to public funding mechanism and criteria. An evidence review", Health Research Board 2017, http://health.gov.ie/wp-content/uploads/2017/03/HRB-AHRFunding-Evidence-Review.pdf

${ }^{4}$ Nordic Committee on Bioethics, "Assisted Reproduction in the Nordic Countries. A comparative study of policies and regulations", Nordic Council of Ministers 2006.

${ }^{5}$ Mohr S., Koch L., (2016), "Transforming social contracts; the social and cultural history of IVF in Denmark." ELSEVIER Journal, Volume 2, https://www.sciencedirect.com/science/article/pii/S2405661816300181\#bbb0080

${ }^{6}$ European Society of Human Reproduction and Embryology.

7 International Federation of Fertility Societies, (2013), "IFFS Surveillance 201" https://c.ymcdn.com/sites/iffs.siteym.com/resource/resmgriffs_surveillance_09-19-13.pdf

${ }^{8}$ Stephenson P., Wagner M. G., (1993), "Tough Choices: In Vitro Fertilization and Reproductive Technologies", Temple University Press Philadelphia.
} 
- utility, which means all the cost for equipment, personnel and locations that would be needed to fulfill a certain ART program. Costs effectiveness ratios for the ART treatment are expressed as the average direct cost of treatment per live birth, calculated as the total ART treatment costs divided by the number of live births. ${ }^{1}$ The effectiveness of this procedure will not be calculated on the basis of the number of the ART performed, but on the basis of successful ART that resulted in the birth of a child. ${ }^{2}$

What is common to all the countries that provide funding to ART, regardless of the extent to which they finance, is their social approach toward the procreative technologies. They don't consider artificial reproduction only as a personal matter, which the individual should provide at his own expenses. Reproductive techniques have an individual as well as a social dimension, as they affect the structure of a society by resizing the concept of the family. The approach of these countries over the artificial procreation shows that the society and the state are sharing the responsibility over the new features of artificial procreation.

\section{Financing Artificial Reproduction in Albania}

The issue of reproduction is not only seen as an individual need based on his own right to procreate or reproduce himself, but in the same time it shows an individual need to be accepted within the social structure. The Albanian society is still rigidly based on the traditional family. Childless couples are not a common reality in Albania and also cases of artificial reproduction are not easily accepted. The state of the Albanian society toward the reproductive techniques is also reflected in the limited efforts of the Albanian legislator to have a complete legal framework on the issue. The reproductive techniques would not be a priority for the legislator as long as the Albanian society will not show interest on the topic. Despite the cultural and social attitudes, other factors that affect the ART provisions are also economic. As a developing country, the Albanian economy is struggling in financing the basic health care. It is important to underline the fact that the health care system in Albania covers the necessary services during pregnancy and after the childbirth, but not the attempts to avoid infertility. ${ }^{3}$ The basic health care financing packet provides the funding of health care services of the reproductive health, including the counseling services before the pregnancy and curative and rehabilitation services during and after pregnancy. ${ }_{4}^{4}$ The artificial reproduction is not mentioned. The infertility treatment is also not mentioned even in the purpose of the reproductive health care. So far, despite the provisions of Reproductive Law, this service is only provided by private clinics.

\footnotetext{
1 Connolly M.P, Hoorens S., Chambers G.M., on behalf of ESHRE Reproduction and Society Task Force (2010), "The costs and consequences of assisted reproductive technology; an economical perspective", Human Reproduction Update, Volume 16, Issue 6, 1 November 2010 https://academic.oup.com/humupd/article /16/6/603/739127

2 Idem, pg 86

${ }^{3}$ Ligj Nr. 8876, datë 4.4.2002 "Për Shëndetin Riprodhues"

4 Ministria e Shëndetësisë, "Paketa bazë e shërbimeve në kujdesin shëndetësor parësor", pg 27 http://www.shendetesia.gov.al/files/userfiles/Shendeti_Publik/Paketa_e_rishikuar_e_miratuar.pdf 
In 2017 the Ministry of Health approved the National Health Strategy 2017- 2021.1 The National Health Strategy recognizes the lack of legislation in the field of artificial reproduction and expresses the necessity to revise the legislation as soon as possible in accordance with the best European practices. The Strategy provides as one of its strategic objectives the need of strengthening sexual and reproductive health services, with an approach throughout the life cycle, based on evidence and vision towards universal coverage, but it avoids any clear specification on artificial reproductive techniques. The fact that the Strategy stresses the need for infertility treatment and sets as a strategic objective the effort to include in the universal coverage of the reproductive health services is a green light for a possible funding of the artificial reproductive techniques in the future.

Private clinics in Albania, which offer the ART services, seems to be very attractive for foreigners as the cost of their services is lower than those of clinics in other European countries, but they still remain relatively high considering the economic living standard in Albania. The cost to benefit from the ART services of a couple is about 5 000 Euros. For an individual the cost tends to be even higher since there are no sperm banks in Albania, and the individual should bear even the cost of its import. In a country like Albania, where the average gross monthly salary is calculated to be about 380 Euros $^{2}$, the cost of the ART services seems to be unbearable for the individual.

The possibility of financing reproductive techniques depends mostly on the demand for such services. The cost of infertility management is determined by the percentage of patients seeking treatment for infertility, its impact on population and the quality of treatment. But until now the Ministry of Health does not possess any data on the number of individuals undergoing through ART, which makes this kind of infertility treatment immeasurable and so impossible to include it as a fundable service. As a first step, it is necessary to calculate the real cost of the artificial reproductive services, what is the need for funding and which should be the requirements in order to avoid unnecessary costs? The legislator, in order to reduce the cost of ART may decide to finance it only in public hospitals. An attempt to include ART services in the public hospitals was made in 2012, when the former Director of the Gynecological University Hospital "Koco Gliozheni", announced that in accordance to the EU project "Medicine of the Future" the ART services would already be offered by the public hospitals and funded by the Security Health Scheme, but until now it remained only a statement. ${ }^{3}$ In accordance to the WHO recommendations the treatment of infertility should be considered as a disease treatment. The WHO emphasizes the need of a universal access to infertility treatments, but their high cost leads to a restriction of

\footnotetext{
${ }^{1}$ Albanian National Health Strategy 2017 - 2021.

2 INSTAT (The institute of Statistics), The average monthly salary and the minimal monthly salary T3 $2014-$ T3 2017 http://www.instat.gov.al/al/themes/pagat-dhe-kosto-e-pun\%C3\%ABs.aspx

3Llambro Z., (2012, October 19), "Fekondimi "In vitro" do te kryhet edhe ne spitalet publike", Panorama Newspaper http://www.panorama.com.al/fekondimi-in-vitro-do-te-kryhet-edhe-ne-spitalet-publike/ retrieved on 24 January 2018
} 
access. Only those who can afford to pay can have the possibility to cure infertility through the conservative way or through the application of ART.

\section{Conclusions}

The fertility treatment is a long and expensive process, which results take time and its productivity is not sure. For this reason the use of reproductive techniques seems to be the other alternative to avoid the infertility consequences. In many European countries artificial reproduction is seen as a health service provided fully or partly by the state. The purpose of this service justifies the fact that these techniques are included in health policies by the states, as infertility is seen as a problem for many European countries and the goal of these techniques is to avoid, whenever it is possible, its consequences. But the inclusion in the health care system of the ART implicates political, social and economic matters. As a post communist country, the Albania economy and its health insurance scheme has faced numerous challenges and the infertility issues were not at the top of the list. ${ }^{1}$ Neither is at the moment. As the Albanian legislator is making the necessary efforts to join the European Union, assisted reproduction can't attract the political attention. But as the number of infertile couples is growing rapidly there are still no concrete policies for the infertility treatment. According to the statistics of the Albanian Institute of Statistics, infertility is becoming a serious concern for our country ${ }^{2}$ In front of this situation is the duty of the legislator to take the necessary measures to reduce and treat infertility. A first step is that of considering the infertility as a disease, as a state of health restriction, which is becoming a really serious health concern for the Albanian society. Including fertility as a prevalent health problem would provide the necessary justification for a future infertility financing plan. As a developing country, Albania can try to include infertility treatment in its national health plan, by trying to finance ART services partially and in accordance with other status or age requirements.

\section{References}

\section{Books}

[1] Albanian National Health Strategy 2017 - 2021.

[2] American Academy of Actuaries, "Fundamental of Insurance: Implications for Health Coverage", July 2008

[3] Ata B., Seli E. (2010), "Economics of assisted reproductive technologies", Current opinion in obstetrics \& gynecology ; 22(3): 183-8.

\footnotetext{
1 Other post communist countries have gone through the same experience.

Nordic Committee on Bioethics, (2006), "Assisted Reproduction in the Nordic Countries. A comparative study of policies and regulations", Nordic Council of Ministers.

2 INSTAT data on infertility: It is shown that the natural addition of the population changes from 63, 932 in 1990 to 34,821 in 2000 and only 14,273 in 2011. This data reflects a significant decrease in the birth rate, although the number of deaths has not changed significantly. The number of births has decreased from 82125 births in 1990 to 51242 in 2000 and 34285 in 2011.
} 
[4] Belgium Law Concerning Medically-Assisted Insemination, 2007.

[5] Committee on Economic, Social and Cultural Rights, "CESCR General Comment No.14: The Right to the Highest Attainable Standard of Health".

[6] Connolly M.P., Hoorens S., Chambers G.M., on behalf of ESHRE Reproduction and Society Task Force, "The costs and consequences of assisted reproductive technology; an economical perspective", Human Reproduction Update, Volume 16, Issue 6, 1 November 2010.

[7] French Human Fertility and Embryology Bill, 2007-2008.

[8] German Social Code V.

[9] Holm S. (1996), "The need for treatment", ed. Evans "Creating the child", Kluwer edt.

[10] International Covenant on Economic, Social and Cultural Rights, adopted on 3 January 1976, United Nations of Human Rights.

[11] International Federation of Fertility Societies, Surveillance 2013.

[12] Katz P., Nachtigall R., Showstack J., "The economic impact of the assisted reproductive technologies", Institute for Health Policy Studies, California USA.

[13] Keane M., Long J., O’Nolan G., Farragher L., “Assisted reproductive technologies: International approaches to public funding mechanism and criteria. An evidence review", Health Research Board 2017

[14] Ligj Nr. 8876, datë 4.4.2002 "Për Shëndetin Riprodhues".

[15] Martin J. (1996), "Prioritizing assisted conception services: A Public health perspective" Evans "Creating the child", edt. Kluwer.

[16] Ministria e Shëndetësisë, "Paketa bazë e shërbimeve në kujdesin shëndetësor parësor".

[17] Mohr S., Koch L., "Transforming social contracts; the social and cultural history of IVF in Denmark." ELSEVIER Journal, Volume 2, June 2016.

[18] N. A. S, N.A.E, I.M and N.R.C, (2001), "Crossing the Quality Chasm: A New Health System for the $21^{\text {st }}$ Century", NA Press, 2001.

[19] Nordic Committee on Bioethics, "Assisted Reproduction in the Nordic Countries. A comparative study of policies and regulations", Nordic Council of Ministers 2006.

[20] Peto Zh. (2006), "Sistemet e mbrojtjes shoqërore" , Shtypshkronja Ekpres, Tirane. 
[21] Service Public Federal Santé Publique, Securité de la Chaine Alimentaire et Environment 20032403, June 4, 2003, p. 32127., The Royal Decree of June 2003.

[22] Stephenson P. Wagner M. G. (1993), “Tough Choices: In Vitro Fertilization and Reproductive Technologies", Temple University Press Philadelphia.

[23] UN, International Conference on Population and Development, Program of Action, 5 - 13 September 1994.

[24] WHO, ICMART, "Revised glossary on ART terminology, 2009", Human Reproduction, Vol. 24, No. 11.

[25] WHO, UN High Commissioner of Human Rights, "The Right to Health", Fact Sheet No.31 